\title{
A PROVINCIAL VIEW OF CAPITAL MOBILITY
}

Tamim Bayoumi

Michael W. Klein

Working Paper No. 5115

\author{
NATIONAL BUREAU OF ECONOMIC RESEARCH \\ 1050 Massachusetts Avenue \\ Cambridge, MA 02138 \\ May 1995
}

We thank Marcelo Bianconi, Peter Isard, Rudi Dornbusch, Richard Clarida, and participants in seminars at the NBER, MIT, and Columbia University for helpful comments. This paper is part of NBER's research program in International Finance and Macroeconomics. Any opinions expressed are those of the authors and not those of the International Monetary Fund, or the National Bureau of Economic Research.

( 1995 by Tamim Bayoumi and Michael W. Klein. All rights reserved. Short sections of text, not to exceed two paragraphs, may be quoted without explicit permission provided that full credit, including $\odot$ notice, is given to the source. 


\title{
A PROVINCIAL VIEW OF \\ CAPITAL MOBILITY
}

\begin{abstract}
This paper develops a method of testing for zones of financial integration based upon intertemporal considerations and applies it to data on Canadian provincial trade. In a financiallyintegrated region individuals smooth consumption with respect to movements in aggregate income. Consumption in that region follows income in that region if individuals use only regional capital markets while consumption follows movements in income in broader regions (e.g. national income or world income) if individuals have access to and use capital markets in those broader regions (e.g. the national or global capital markets, respectively). We derive a specification which measures the impact of differential levels of access to capital markets-different zones of capital mobility--on the relationship between the regional trade balance and regional, national and global income. This empirical specification is tested using data on trade balances across Canadian provinces. The results indicate full capital mobility within Canada but only partial capital mobility between Canada and the rest of the world.
\end{abstract}

Tamim Bayoumi

Research Department

International Monetary Fund

700 19th Street, NW

Washington, DC 20431
Michael W. Klein

Fletcher School of Law and Diplomacy

Tufts University

Medford, MA 02155

and NBER 


\section{Introduction}

Capital mobility is one of the cornerstones of international finance. By allowing countries to borrow and lend between each other, open international capital markets allow domestic savings to be channeled into their most productive uses, raising the efficiency of worldwide investment and letting individuals chose their preferred path for consumption. The level of international capital mobility, however, remains an unresolved issue empirically. Tests based on comparisons of interest rates such as onshore-offshore differentials tend to indicate a very high level of capital mobility between countries. However, work looking at the behavior of real variables implied by open capital markets, whether it be saving and investment correlations, consumption behavior across countries, or the intertemporal approach to the balance of payments, generally find that the external balance is less variable than might be expected if capital mobility was high. 1

This paper extends this work on the behavior of the external balance, using the intertemporal approach to the balance of payments. Earlier work in this field has looked at the behavior of the current account, while we focus on the behavior of the trade balance. ${ }^{2}$ Switching to the trade balance allows us to develop a considerably more general model than earlier authors in terms of its assumptions about the behavior of the real interest rate and the type of assets which can be owned by individuals. It also produces a simpler empirical estimating equation.

We also extend the analysis by developing a method of looking a differences in capital mobility between groups of countries. Empirical tests of capital mobility typically look for either the existence or the absence of capital mobility between one country and the rest of the world. An alternative scenario is that there are limited zones of financial integration among sets of countries or within certain regions. For example, capital may be more mobile within Europe than between

\footnotetext{
1 Obstfeld (1994b) provides a survey of the literature on measuring international capital mobility. Ghosh (forthcoming), Lewis (1993) and Tesar and Werner (1992) provide evidence that international capital mobility is limited based on the behavior of real variables.

2 Overviews of the intertemporal approach include Frenkel and Razin (1987) and Obstfeld and Rogoff (1994).
} 
Europe and the rest of the world, reflecting differences in costs, information, or legal systems. The model that we develop allows for such differences in mobility between regions.

The model is then applied to data on trade balances across Canadian provinces. The zones of mobility concept is used to differentiate capital mobility among residents of different Canadian provinces from capital mobility between Canadian residents and the rest of the world. Canada has a national banking system, unified financial laws across provinces, and a common currency, factors which make borrowing and lending within Canada closely resemble models in which capital is assumed to flow freely. Different provinces across Canada also have markedly different economic structures and disturbances, providing a notable potential for consumption smoothing. Thus, intraCanadian trade provides a natural benchmark of our test of perfect capital mobility. ${ }^{3}$ Our results indicate that capital is fully mobile within Canada, as expected given its financial structure, but that it is only partially mobile between Canada and the rest of the world. We wish to stress, however, that the methodology we develop in this paper is very general and can be extended beyond the particular case we study here to a broader search for zones of international financial integration. A natural extension of this specification is to test for capital mobility within a group of countries and between those countries and the rest of the world.

The theory behind our specification is developed in Section 2. In section 2.1 we present a representative agent model and in Section 2.2 we allow for heterogeneous access to capital markets across individuals in a province. The data are discussed in Section 3. Section 4 presents our empirical specification while Section 5 contains our results. Section 6 offers some concluding remarks.

\footnotetext{
${ }^{3}$ Other recent work focusing on intra-national data sets in a variety of contexts includes Barro and Sala-iMartin (1991), Bayoumi and Rose (1993), Bayoumi and McDonald (1994), Blanchard and Katz (1992) and Engel and Rogers (1994).
} 


\section{Trade Balances and Regions of Economic Integration}

The theory of intertemporal trade is based upon the behavior of forward-looking individuals whose decisions reflect optimal responses to economic conditions. ${ }^{4}$ In this section we develop a model of the trade balance with a focus on optimal intertemporal consumption behavior. ${ }^{5}$ While retaining most of the features of a standard exercise of this type, our approach is more general. We allow for variability of real interest rates, for equity as well as bonds, and for limited capital mobility as represented by zones of capital market integration. Borrowing and lending takes place more easily within these zones than between one zone and another. 6

A natural candidate for a zone of capital market integration is a single country since in many countries (such as Canada) there is a common federal law and a national banking system. In recognition of this, and in anticipation of the empirical results that follow, we model the consumption decisions of representative individuals in the $k$ provinces of a country. We begin in section 2.1 by assuming that these individuals are able to borrow and lend within the country but not across its borders. Section 2.2 allows for differences in access to international capital markets across individuals.

\subsection{Trade Balances in an Integrated Region}

The representative consumer in each province maximizes the expected value of a timeseparable utility function with a constant subjective rate of discount equal to $\rho$ :

$$
\max E_{t}\left(\sum_{j=0} \frac{u\left(c_{t+j}\right)}{(1+\rho)^{j}}\right)
$$

\footnotetext{
${ }_{5}^{4}$ Overviews of the intertemporal approach include Frenkel and Razin (1987) and Obstfeld and Rogoff (1994). 5 An alternative strategy is to include explicit modeling of production and investment decisions. For example, Glick and Rogoff (1993) model the current account based upon production and a cost of adjustment to investment.

${ }^{6}$ This obviously subsumes the case of perfect international capital mobility since the zone of capital market integration in this case is the entire world.
} 
where $E_{t}$ is the expectations operator, $c$ is consumption, subscripts refer to time periods and the superscript $i$ refers to the province. The consumption decision is subject to the budget constraint that the discounted value of consumption equals wealth, defined as the discounted value of future income plus the value of initial assets. 7

$$
\sum_{j=0}^{\infty} \frac{c_{t+j}^{i}}{\prod_{k=0}^{j}\left(1+r_{t+k}\right)}=\sum_{j=0}^{\infty} \frac{y_{t+j}^{i}}{\prod_{k=0}^{j}\left(1+r_{t+k}\right)}+A_{t}^{i} \equiv Q_{t}^{i}
$$

where $y$ represents provincially-produced income available for consumption, $r$ is the real interest rate, $A^{i}$ is net asset holdings for the province relative to the rest of the country and $Q_{t}^{i}$ is the net present value of future consumption or, equivalently, the wealth of the province. Net assets can be of any type (conventional debt, equity) so long as certainty equivalence holds, i.e. the value of the asset is equal to the discounted value of expected future income. Provincially-produced income available for consumption is equal to gross provincial product (the provincial analogue to GDP) less investment less provincial government consumption. ${ }^{8}$ The lack of a provincial superscript on the interest rate reflects the assumption that the national capital market is integrated and hence provinces face a common (and time-varying) real interest rate.

The first-order condition for this problem is the familiar

[3]

$$
\frac{E_{t} U^{\prime}\left(c_{t+1}^{i}\right)}{U^{\prime}\left(c_{t}^{i}\right)}=\frac{1+\rho}{1+r_{t}}
$$

\footnotetext{
${ }^{7}$ We impose here the transversality condition that rules out the possibility of Ponzi game-type behavior. ${ }^{8}$ Issues related to net federal transfers are discussed in the empirical section.
} 
In the commonly-studied case where there is a constant coefficient of relative risk aversion equal to $\theta$, the utility function takes the form $U\left(c_{t}{ }_{t}\right)=\left(c_{t}^{i}\right)^{1-\theta} /(1-\theta)$ and [3] takes the form;

$$
\frac{E_{t}\left(C_{t+1}^{i}\right)^{\theta}}{\left(C_{t}^{j}\right)^{\theta}}=\frac{1+r_{t}}{1+p}
$$

The first-order condition [4] and the budget constraint [2] imply that consumption in any period $t$ is a fraction of total wealth.

[5]

$$
c_{i}=\frac{Q_{t}^{i}}{E_{t} \sum_{j=0}^{\infty} \frac{\prod_{k=0}^{j}\left(1+r_{t+k}\right)^{\frac{(1-\theta)}{\theta}}}{(1+\rho)^{j / \theta}}}
$$

For any two provinces $i$ and $j$ with integrated capital markets, and thus the same expected path of interest rates $r_{t}$, and a common discount factor $\rho$

$$
\frac{c_{t}^{i}}{Q_{t}^{i}}=\frac{c_{t}^{j}}{Q_{t}^{j}}
$$

Extending equation [6] across all provinces implies that the ratio of national consumption to national wealth equals the ratio of consumption to wealth in any province. If the nation's capital market is not integrated with the rest of the world then national consumption equals national income. Accordingly,

[7]

$$
\frac{c_{t}^{i}}{Q_{t}^{\prime}}=\frac{c_{t}^{N}}{Q_{t}^{N}}=\frac{y_{t}^{N}}{Q_{t}^{N}}
$$


where the superscript $N$ refers to the nation as a whole.

An equation for the provincial trade balance, $\mathrm{TB}_{\mathrm{t}}^{\mathrm{i}}$, can be derived by noting that the trade balance equals the difference between provincial income and provincial consumption;

$$
T B_{t}^{i}=Y_{t}^{i}-\frac{Q_{t}^{i}}{Q_{t}^{N}} Y_{t}^{N}
$$

Equation [8] demonstrates the scope to which capital markets can be used to smooth provincial consumption through trade. Differences between provincial income and national income will be manifested in the trade balance but aggregate changes in income common to all provinces will be met by concomitant movements in consumption.

We derive from [8] an estimating equation in first differences which includes expectational error terms. As shown in the appendix, we obtain the following equation for the change in the trade balance:

$$
\Delta T B_{t}^{i}=\Delta Y_{t}^{i}-\Delta Y_{t}^{N} \frac{C_{t}^{i}}{C_{t}^{N}}+\epsilon_{t}
$$

[9]

where the error, $\epsilon_{t}$, is a linear combination of the 'news' about current wealth of the province, $\epsilon_{t} i_{t}$ and 'news' about current wealth of the nation, $\epsilon^{\mathrm{N}}$ at time $t$ obtained between times $t-1$ and $t .9$ The 'news' about current provincial wealth is;

${ }^{9}$ See Deaton (1992) (chapter 3) for a similar derivation in the context of the permanent income hypothesis. 


$$
\epsilon_{t}^{i}=\left(E_{t}-E_{t-1}\right) \sum_{j=0}^{\infty} \frac{y_{t+j}^{i}-T B_{t+j}^{i}}{\prod_{k=0}^{j}\left(1+r_{t+k}\right)}
$$

[10]

and an analogous definition applies to $\epsilon^{N}$.

Equation [9] is the basic building block of our study of Canadian provincial trade. The change in the provincial trade balance moves with changes in provincial income to the extent that these changes in provincial income do not alter the expected discounted value of provincial wealth. Thus a temporary change in provincial income has a bigger effects on the trade balance (and a smaller effect on $\epsilon^{i}$ ) than a permanent change in provincial income. The change in national income term reflects the constraint that, under limited international capital mobility, provincial trade balances must sum to zero. This constraint is, of course, more general and holds for any region with integrated capital markets. For example, if capital markets were integrated across countries in a region (but not outside the region) we could redefine what we have called "provinces" as countries and "the nation" as the region as a whole. In the polar case of full international capital mobility, "the nation" would be the entire world. Even in this case, the extent to which consumption can be smoothed within a country is limited by changes in income for the world as a whole.

Several aspects of our trade-balance based approach distinguish it from previous work on the intertemporal approach that focuses on the current account. As the current account depends upon income from capital in addition to domestic income available for consumption, such an approach 
requires explicit assumptions about the path for the real interest rate and the type of debt. ${ }^{10} \mathrm{By}$ contrast, our approach allows the real interest rate to vary endogenously so as to equate aggregate consumption with the income available for such consumption. It also allows us to be more general about the type of assets that consumers can own (assuming that certainty equivalence holds).

Despite this greater level of generality, we obtain an exact equation involving no approximations.

\subsection{Heterogeneous Access to Capital Markets}

As noted above, equation [9] is a very general relationship which will hold in any financiallyintegrated area. In particular, if there is full international capital mobility the above analysis implies that the expected change in the trade balance for the province is:

$$
\Delta T B_{t}^{i}=\Delta Y_{t}^{i}-\frac{c_{t}^{i}}{c_{t}^{W}} \Delta Y_{t}^{W}+\epsilon_{t}
$$

where the superscript W refers to the entire world.

An assumption in the development of equation [9] that is dropped for equation [11] is that there is no international borrowing or lending. We can also consider an intermediate situation where access to international markets is limited.

Ideally, one would develop at a fully optimizing model involving different costs of access between markets to look at this question. However, we adopt a somewhat simpler approach based on the type of model developed by Campbell and Mankiw (amongst others) to look at relationship

\footnotetext{
${ }^{10}$ Work based on the current account focuses on the relationship $C A=Y+r A-C$ and $C A=\Delta A$ where $Y$ is income available for consumption (see Obstfeld and Rogoff 1994 and references therein). In these models the real interest rate enters directly by multiplying asset holdings, $A$. By contrast, we use $T B=Y-C$. The only assumption about $A$ is that in equation [2], namely that it equals the discounted sum of expected future trade deficits, which is equivalent to assuming certainty equivalence.
} 
between conusmption and income. ${ }^{11}$ Assume that there are two representative consumers in each province who differ in their ability to borrow or lend outside the nation. ${ }^{12}$ If the consumer who can borrow and lend internationally has a proportion $\lambda$ of total income while the consumer who is restricted to borrowing and lending within the nation has the remaining (1- $\lambda)$ of total income, the expected change in the overall trade balance for province $i$ is a weighted average of the behavior expected if international capital mobility is perfect and that in which capital mobility is limited within Canada. This implies:

$$
\Delta T B_{t}^{i}=\Delta Y_{t}^{i}-\lambda \frac{c_{t}^{i}}{c_{t}^{W}} \Delta Y_{t}^{W}-(1-\lambda) \frac{c_{t}^{i}}{c_{t}^{N}} \Delta Y_{t}^{N}+\epsilon_{t}
$$

where $\epsilon_{\mathrm{t}}$ is the weighted sum of the composite errors in [9] and [11].

It is worth emphasizing here the difference of the estimation equation [12] from the type of equation that would arise from the standard analysis that assumes perfect capital mobility. In the simplest form of that framework the provincial trade balance would move in response to temporary changes in provincial income. The term representing the change in world income recognizes the impact of the aggregate resource constraint on behavior and how it limits the scope for risk-sharing and consumption smoothing. The term representing national income captures the same effect in a world of limited international capital mobility.

\section{A First Look at the Data}

This section discusses the data set of provincial Canadian trade balances and income available for consumption used to test the theory discussed above. Also in this section we report on some of ${ }^{*}$

${ }_{11}$ Campbell and Mankiw $(1989,1991)$.

12 We also assume that the capital market is sufficiently segmented such that the two consumers within the province do not borrow or lend with each other. 
the characteristics of this relatively unfamiliar data and provide some statistics suggested by the theory.

Annual Provincial National Accounts for real and nominal expenditures and nominal income (as well as population) are published by Statistics Canada for the ten provinces and two territories of Canada. ${ }^{13}$ Provincial expenditures are subdivided into domestic categories such as public and private consumption and investment but do not include spending on exports and imports. ${ }^{14}$ The income accounts divide nominal gross provincial product (the provincial equivalent of gross national product) into categories such as wages and profits as well as nominal net exports of goods and services. Net exports are calculated indirectly as the difference between total provincial expenditures (calculated from the expenditure data) and gross provincial product (calculated from the income data). Hence any statistical discrepancies are included in net exports. The nominal data start in 1961, while the real data start in 1971. Both end in 1992.

These accounts provide all the data needed to estimate the model. Per capita real domestic income available for consumption (hereafter simply income) was calculated as nominal gross provincial product minus government consumption and total investment, deflated by population and the implicit consumption deflator. Per capita real trade balances were calculated as nominal net exports, again deflated by population and the consumption deflator. 15

There are two issues associated with the data which deserve further discussion. The first is the inclusion of a statistical discrepancy in the data for net exports. According to the national

\footnotetext{
${ }^{13}$ These are, in descending order of size (based on 1992 income), Ontario, Quebec, British Columbia, Alberta, Manitoba, Saskatchewan, Nova Scotia, New Brunswick, Newfoundland, the combined Yukon and Northwest territories and Prince Edward Islands. Data are available for the aggregate of the Yukon and the Northwest territories only over the full sample period so the two are treated as an eleventh province in the . estimation.

14 Estimates of exports and imports do exist for certain years, sce Messinger (1993).

${ }^{15}$ The consumption deflator was used on both series since the model is concerned with the use of the trade balance to smooth consumption over time, hence all nominal values should be converted into their equivalent level of consumption. From 1971 onwards, individual provincial consumption deflators were used; prior to 1971 these deflators do not exist, so the national consumption deflator was spliced onto the series.
} 
accounts identity, net exports should equal the difference between total expenditure and income. However, in most national accounts net exports are derived from direct estimates of exports and imports. The difference between the direct estimate and that implied by the national accounts identity is then labeled a statistical discrepancy. The provincial accounts do not contain a direct measure of net exports, however, and by assuming that the national accounts identity holds net exports are derived as a residual. Potentially this could affect our regression results since there would be a correlation between changes in income and the trade balance due to the measurement of provincial expenditures and product with error. We estimate equations using instrumental variables (as discussed further below), however, and therefore the error present in the measurement of provincial expenditures and product only affect estimates of net exports to the extent that it is predictable. We consider it unlikely that the predictable errors in provincial estimates of product and expenditure are large enough to bias the coefficient estimates significantly.

The second issue concerns net transfers from the Canadian federal government to the provinces. The federal government has a budget constraint with respect to the whole of Canada but not with respect to individual provinces. Different provinces may either receive or contribute net income to the federal government. Both income and the trade balance should be adjusted for these flows since they are, in effect, unrequited transfers and hence income for the province. We measured these transfers as the deviation between per capita provincial net lending by the federal government, which does not have to satisfy a budget constraint, and per capita national net lending by the federal government, which does. This difference was added to the provincial series on per capita income available for consumption and the per capita trade balance. Hence, the series used in estimation were calculated as: 16

\footnotetext{
${ }^{16}$ There is one further issue, which is that in the regional accounts a significant part of federal net lending is assigned to Canadian citizens overseas (the so-called snowbirds). So as to make the transfers within Canada sum to zero, this part of net lending was eliminated from the per capital data on aggregate Canadian federal net lending in this calculation.
} 


$$
\begin{gathered}
T B_{t}^{i}=\frac{T B N A_{t}^{i}}{P O P_{t}^{i} / P_{t}^{i}}+\frac{N L_{t}^{i}}{P O P_{t}^{i} / P_{t}^{i}}-\frac{N L_{t}^{C A N}}{P O P_{t}^{C A N} / P_{t}^{C A N}} \\
Y_{t}^{i}=\frac{\left(G P P_{t}^{i}-G_{t}^{i}-I_{t}^{i}\right)}{P O P_{t}^{i} / P_{t}^{i}}+\frac{N L_{t}^{i}}{P O P_{t}^{i} / P_{t}^{i}}-\frac{N L_{t}^{C A N}}{P O P_{t}^{C A N} / P_{t}^{C A N}}
\end{gathered}
$$

where TB is the trade balance per capita used in estimation, TBNA is the total trade balance from the national accounts, NL is net lending by the federal government, POP is population, $\mathrm{P}$ is the consumption deflator, $\mathrm{Y}$ is income available for consumption, GPP is gross provincial product, $\mathrm{G}$ is government consumption, and $\mathrm{I}$ is total investment. Superscript $i$ represents province $i$, while superscript $C A N$ represents data for Canada as a whole.

Before turning to results from the formal model, we conclude this section with some timeseries plots of our data and some summary statistics. Chart 1 shows the evolution of the first difference of per capita values of real income available for consumption, the trade balance, and real gross provincial product for Canada as a whole and for each province separately, while Chart 2 illustrates levels of the same series. ${ }^{17}$ The striking feature of the charts is the close relationship between provincial income for consumption and the provincial trade balance. ${ }^{18}$ This relationship holds more closely for the smaller provinces, such as Yukon and Northwest territories and Price Edward Island, and less closely for both the larger provinces, such as Ontario, and for

${ }^{17}$ All three series were adjusted for the federal transfers discussed above. The results without this adjustment (not reported) were similar. For consistency real gross provincial product was calculated using the consumption deflator, since the other series were also calculated using this deflator.

${ }^{18}$ By comparison, the relationship between real gross provincial product, a more traditional measure of activity, and the trade balance is much less close. 
Canada as a whole. This is a result we would expect to find if there was intra-Canadian financial integration but limited capital mobility between Canada and the rest of the world. In that case there would be more limited scope for consumption smoothing for large provinces through movements in their trade balance than for small provinces. Movements in income in large provinces represent more closely movements in total income in the financially-integrated region, ceterus paribus, and thus large provinces have less opportunity to smooth consumption.

These visual impressions can be supplemented by some simple statistics. Tables 1 and 2 show correlations and standard deviations of the change in real provincial product, income, and the trade balance for each province and for Canada as a whole. In addition, to give a sense of relative size of the provinces, Table 1 also reports GDP in 1992 for each province. The correlation between income and the trade balance is generally higher for the smaller provinces than for the larger ones. For example, the lowest three correlations are found for the largest three provinces and the lowest correlation is for the whole of Canada. ${ }^{19}$ There is also a close connection between the variability of the trade balance and the variability of income available for consumption. Note that the variability of income is markedly larger for Alberta, Saskatchewan and the Yukon and Northwest territories than for the other provinces. The standard deviation of the change in the trade balance is uniformly closer to that for change in income than that for the change in real product.

The finding that there is a closer connection between income and the trade balance for small provinces than for large provinces or for Canada as a whole is consistent with the view that capital mobility is high within Canada, but lower between Canada and the rest of the world. Small provinces, whose financial relations are largely within Canada, are able to use Canadian financial markets to smooth consumption. For Canada as a whole, however, capital mobility with the rest of

${ }^{19}$ By contrast, the correlation between real product and the trade balance, while positive, is relatively low. 
the world is more limited. 20 This also limits the ability of some of the larger provinces to use the capital markets to smooth consumption. A more formal test of this hypothesis is investigated in the next section.

\section{Empirical Specification}

Equations [9], [11] and [12] provide alternative specifications for provincial trade balances depending upon the extent to which Canadian capital markets are integrated with those of the rest of the world. If all Canadian consumers have access to a single, global capital market then equation [11] would hold. Our implementation recognizes that capital markets across industrial countries are relatively open while those in many developing countries continue to be effectively closed to international transactions. Accordingly, changes in total OECD income (from OECD National Accounts) were used as our proxy for changes in income in the world as a whole. The empirical counterpart to equation [11] then becomes:

$$
\Delta T B_{t}^{i}=\alpha^{i}+\beta^{i}\left(\Delta Y_{t}^{i}-\frac{C_{t}^{i}}{C_{t}^{O E C D}} \Delta Y_{t}^{O E C D}\right)+\epsilon_{t}^{i}
$$

where $\epsilon_{t}{ }_{t}$ is uncorrelated with all information know in period $t-1$ or earlier. If Canadian capital markets are fully integrated with those in the rest of the OECD, then the coefficients on changes in relative income, $\beta_{\mathrm{i}}$, should all equal 1 and the constant terms should all equal 0 .

As discussed earlier, a more general approach defines zones of capital mobility and assumes that some consumers have access to more geographically diverse capital markets than others. Equation [15] is an empirical specification matching equation [12] in which it is assumed that a

\footnotetext{
${ }^{20}$ Obstfeld (1994a) and Bayoumi and MacDonald (1994) both conclude that Canada as a whole fails simple tests of consumption smoothing.
} 
proportion $\lambda$ of income in a province goes to consumers who have access to world capital markets while the remainder goes to consumers limited to the national capital market.

$$
\Delta T B_{t}^{i}=\alpha^{i}+\beta^{i}\left(\Delta Y_{t}^{i}-\frac{C_{t}^{i}}{C_{t}^{O E C D}} \Delta Y_{t}^{O E C B}\right)-(1-\lambda)\left(\frac{C_{t}^{i}}{C_{t}^{C A N}} \Delta Y_{t}^{C A N}-\frac{C_{t}^{i}}{C_{t}^{O E C D}} \Delta Y_{t}^{O E C B}+\epsilon_{t}^{i}\right.
$$

where $\alpha^{\mathrm{i}}, \beta^{\mathrm{i}}$, and $\lambda^{\mathrm{i}}$ are estimated coefficients, and again $\epsilon_{\mathrm{t}}^{\mathrm{i}}$ is an error which is uncorrelated with information known at $t-1 .^{21}$ The $\beta^{\mathrm{i}}$ coefficients now indicate the proportion of activity associated with those who smooth consumption within either Canada or the OECD. The $\lambda^{i}$ coefficients measure the proportion of activity associated with those who smooth consumption through borrowing internationally. For example, if $\beta^{i}=1$ and $\lambda^{i}=0.4$ for a given province, that would indicate that 40 percent of consumption was associated with those with access to global capital markets while the remaining 60 percent was associated with those with access to capital markets only within Canada. 22

This formulation identifies only two types of capital market access, intra-national and international. 23 Our specification allows for the possibility that some consumers lack access even to national Canadian capital markets. These consumers would behave in a completely autarkic manner which would be reflected in a coefficient on provincial income that was less than one. For example, if $\beta^{i}=0.8$ and $\lambda^{i}=0.5$ this would imply that 20 percent of consumption was not smoothed at all, even with respect to the rest of Canada, 40 percent was smoothed only within

\footnotetext{
${ }^{21}$ Equation [15] differs from [12] because it adds and subtracts the term multiplying the change in world income from the right-hand side. This facilitates comparison between [15] and [14]. 22 Although the model was derived by assuming that people either have full access to international capital markets or no access at all, these proportional can also be thought of as reflecting partial access to such markets caused, for example, by higher transactions costs.

23 In theory other zones of capital mobility, such as North America, could also be considered although our empirical results indicate this is not necessary.
} 
Canada, while the remaining 40 percent was smoothed with respect to the OECD. Hence, equation [15] allows us to measure the effect on provincial trade balances arising from consumers who use only local capital markets (the proportion $\left(1-\beta^{\mathrm{i}}\right)$ ), from those who use national capital markets (the proportion $\beta^{i}\left(1-\lambda^{i}\right)$ ) and from those who use global capital markets (the proportion $\beta^{i} \lambda^{i}$ ).

The implied equation for the Canadian trade balance is:

$$
\Delta T B_{t}^{C A N}=\alpha^{C A N}+\lambda^{C A N}\left(\Delta Y_{t}^{C A N}-\frac{C_{t}^{C A N}}{C_{t}^{O E C D}} \Delta Y_{t}^{O E C B}\right)+\epsilon_{t}^{C A N}
$$

If the $\beta^{\mathrm{i}}$ and $\lambda^{\mathrm{i}}$ coefficients are equal across provinces, this implies that $\lambda^{\mathrm{CAN}}=\lambda^{\mathrm{i}}$ for all $i$, a cross equation restriction which can be imposed as a further test the validity of the model.

Finally, it is important to recall that the error term includes revisions in expectations between time $t-1$ and time $t$. As a result, it is necessary to use lagged instrumental variables in the estimation. We use past changes in income and the trade balance as our instruments. Past changes in income should be useful in helping to predict current changes in income. Since consumption is smoothed over time, it follows that the past changes in the trade balance will also include information about changes in income. Accordingly, in addition to constant terms, the first and second lags of the change in provincial income relative to the rest of the $O E C D$, the change in provincial income relative to the Canada, and the provincial and national trade balances were used as instruments.

\section{Results}

Table 3 shows the results from estimating equation [14] using a panel which includes data on each province and aggregate data for Canada as a whole. The first column, which shows the estimated constant terms for each equation, indicates that all of the estimated constant terms are 
small and insignificantly different from zero. As shown in the lower part of the Tables, a Wald test of their joint significance also indicates that they are insignificantly different from zero, a result which holds for all other estimates in this paper. By contrast, the estimated coefficients on relative income are all highly significant. Many of these coefficients are either close to, or in some cases exceed, the value of unity which would occur if all consumers had full access to global capital markets. Indeed, 8 of the 11 provinces have coefficient estimates which are insignificantly different from unity on an individual basis. Paradoxically, among the three provinces that fail this test are two of the largest and most important; Ontario, which makes up some 40 percent of the Canadian economy and British Columbia, the largest west coast province in economic terms. The rejection of optimality in these two provinces is particularly surprising since Toronto and Vancouver are major centers of financial intermediation. It therefore appears unlikely that consumers in these provinces are less well provided with financial intermediation than those in the provinces which do not reject optimality. The aggregate Canadian equation also rejects the restriction that the coefficient is unity. Indeed, at 0.52 , the estimated coefficient on the change in relative income in the Canadian regression is lower than that estimated for any of the provinces individually. 24

A Wald test that all of the coefficients on relative income are jointly equal to unity, and hence that all consumers have full access to global capital markets, is rejected whether or not the aggregate Canadian data is included. The weaker restriction that coefficients are equal across provinces is also rejected by the data. Hence, the results appear to indicate that capital mobility is lower in many of the larger and more economically important provinces than in smaller and less important ones. In addition, results from aggregate Canadian data show lower access to capital markets than do the results from individual provinces.

\footnotetext{
${ }^{24}$ On the other hand, despite the simplicity of the specification the Durbin-Watson statistics, which are reported for each provincial equation, indicate that autocorrelation is not a problem in the regressions, while the adjusted R-squared values indicate that the regressions explain over half of the variance in the trade balance for all of the provinces, and just under half for Canada as a whole.
} 
One explanation for these results is that some consumers only have access to Canadian financial markets. As discussed earlier, if this is correct then the change in Canadian income should also be included in the regression. The omission of this variable will cause the coefficient estimates on the change in income to be biased downward because there will generally be a positive correlation between the change in provincial income and the change in Canadian income and Canadian income enters the equation with a negative sign. This bias will tend to be largest for the more important provinces, since their greater importance in aggregate Canadian activity will tend to increase the correlation between changes in their income and changes in aggregate Canadian income. This explanation also resolves the question of why the result for Canada as a whole indicates lower access to capital markets than do the results for individual provinces.

The results from the extended model, which allows for differential access to national and international capital markets, are reported in Table 4. ${ }^{25}$ As in Table 3, the coefficients on the change in provincial income relative to the rest of the OECD (that is, the $\beta^{i}$ s) are large and generally significant. Unlike the simpler specification, however, all the coefficients but for British Columbia are now insignificantly different from unity both individually and jointly which implies that all individuals smooth their consumption, at least within Canada. The estimated coefficient on provincial income rises in this specification for all provinces but for British Columbia which is consistent with the view that the original specification generated a downward bias in these coefficients. It is noteworthy that the largest percentage change in coefficients between Tables 3 and 4 is in the case of Ontario while Quebec, the second largest province, has the third largest percentage change in its coefficient when comparing Tables 3 and 4.

${ }^{25}$ The constant terms, which are not reported, were uniformly small and insignificant. 
The coefficients on the change in income in Canada relative to the OECD generally have the expected negative sign with the exception of the regression for British Columbia. ${ }^{26}$ Although individual tests indicate that only two of the coefficients are significantly different from zero, the joint hypothesis that all of the coefficients are zero is easily rejected. The subsidiary hypothesis that all of the coefficients are equal, however, is accepted. So is the cross equation restriction with the regression for the aggregate Canadian data discussed earlier (not reported). ${ }^{27}$ Hence, the results indicate intra-national Canadian capital mobility but a significant and uniform wedge between Canadian capital markets and their global counterparts. 28

The coefficient restrictions discussed above point to a highly simplified version of equations [15] and [16]. In the provincial regressions the constant terms are eliminated, the coefficients on the change in provincial income relative to OECD income are constrained to be unity and the coefficients on changes in Canadian income relative to the OECD are constrained to be equal across provinces. The coefficient on the change in Canadian income relative to OECD income in the aggregate Canadian regression is 1 minus the coefficient on Canadian income in the provincial regressions. These restrictions are summarized in [17];

\footnotetext{
${ }^{26}$ British Columbia is the one province where the new specification generates a significant deterioration in the empirical results.

27 The Canadian results in Table 4 are identical with those in Table 3, reflecting the fact that since neither the specification nor the instrument set were changed.

28 The Durbin-Watson statistics in Table 4 indicate no problems with autocorrelation, while the level of fit is similar to that found in Table 3.
} 


$$
\begin{gathered}
\Delta T B_{t}^{i}=\left(\Delta Y_{t}^{i}-\frac{C_{t}^{i}}{C_{t}^{O E C D}} \Delta Y_{t}^{O E C D}-(1-\lambda)\left(\frac{C_{t}^{i}}{C_{t}^{C A N}} \Delta Y_{t}^{C A N}-\frac{C_{t}^{i}}{C_{t}^{O E C D}} \Delta Y_{t}^{O E C D}\right)+\epsilon_{t}^{i}\right. \\
\Delta T B_{t}^{C A N}=\lambda\left(\Delta Y_{t}^{C A N}-\frac{C_{t}^{C A N}}{C_{t}^{O E C D}} \Delta Y_{t}^{O E C B}+\epsilon_{t}^{C A N}\right.
\end{gathered}
$$

This equation explains the behavior of the trade balances of the eleven provinces and that of Canada as a whole using only one estimated coefficient, $\lambda$, which measures the percentage of consumption associated with those who use global capital markets.

The results from estimating equations [17] are shown in Table 5. The estimate of $(1-\lambda)$ is highly significant and indicates that $\mathbf{4 5}$ percent of consumption is associated with those who are constrained to capital markets within Canada. Since the coefficients on provincial income are constrained to be unity, this implies the remaining 55 percent of consumption is associated with those with access to global capital markets. In short, the results indicate that just over half of all Canadian income available for consumption is controlled by consumers who use global capital markets to smooth consumption.

Table 5 also reports the associated Durbin-Watson and adjusted $R$ squared statistics for each provincial equation. In spite of the simplicity of the specification, the Durbin Watson statistics indicate that autocorrelation is not a problem in the equations. The adjusted R-squared statistics indicate no noticeable deterioration in the fit of the data compared to the earlier specifications. Indeed, in many cases the statistics rise, reflecting the greater parsimony of the specification. Two further experiments were conducted as a test of the robustness of the results. One possibility is that the close correlation between changes in income and the trade balance largely 
reflects the adjustment for federal net lending which were included in the series. To investigate this possibility, the specifications were rerun using data in which these adjustments were excluded. The results, which are not reported for the sake of brevity, were very similar to those discussed above. For example, the final estimate of $(1-\lambda)$ was 0.43 , rather than 0.45 . Finally, to see if the results are sensitive to the choice of instruments, the specifications were rerun using only first lags of original instruments, rather than first and second lags. Again, the results, which are not reported, were similar to the main case (the final estimate of $(1-\lambda)$ was 0.43$)$, although, as expected from a smaller instrument set, the coefficients were less precisely estimated. Other instrument sets, as well as estimation using least squares, also produced similar results to the main case.

\section{Conclusions}

This paper develops a method of testing for zones of financial integration based upon intertemporal considerations and applies it to data on Canadian provincial trade. The model is based upon the result that individuals in a financially-integrated region smooth consumption with respect to movements in aggregate income in that region. Thus regional consumption follows regional income if individuals use only regional capital markets while it follows national income or global income if individuals use national or world capital markets, respectively. We derive a specification which measures the impact of differential levels of access to capital markets-different zones of capital mobility-on the relationship between the regional trade balance and regional, national and global income.

In addition to identifying the impact of different zones of capital mobility, this paper differs from most earlier work on the intertemporal approach to the balance of payments in two ways. First, we do not assume that the real interest rate is constant over time. Indeed, movements in aggregate income, and hence, implicitly, real interest rates is our major identifying assumption. 
Second, we have derived an exact intertemporal equation for the trade balance rather than the current account. While there is no theoretical preference between the two concepts, on a practical level the inclusion of nominal rather than real interest payments in calculations of the current account means that the trade balance is probably a preferable aggregate.

The model was tested using data on trade balances across Canadian provinces. The results indicate full capital mobility within Canada. Intertemporal trade between Canada and the rest of the world appears to be only midway between optimal behavior in the presence of full capital mobility and the behavior that would emerge under national capital-market autarky.

These results are interesting on both a methodological and empirical level. Methodologically, we are unaware of any other approach which enables one to identify zones of capital mobility where some individuals having access to more geographically diverse capital markets than others. Empirically, these results provide a benchmark against which to compare other result using this approach. The fact that the test indicates that capital mobility is high within the Canadian currency union, a region which is highly integrated financially, provides a valuable yardstick against which to measure behavior between countries. It also suggests a stylized fact that any equilibrium explanation of international behavior should take into account. The extension of this work to international data is our next project. 


\section{APPENDIX}

In this appendix we derive equation [9] in the text. First, we multiply each side of [8] by $\mathrm{Q}^{\mathrm{N}}{ }_{\mathrm{t}}$ and then quasi-difference. After some manipulation this yields

$$
\begin{aligned}
\Delta T B_{t}^{i} Q_{t}^{N}+T B_{t-1}^{i}\left(Q_{t}^{i}-\left(1+r_{t-1}\right)\right. & \left.Q_{t-1}^{N}\right) \\
& =\Delta Y_{t}^{i} Q_{t}^{N}+Y_{t-1}^{i}\left(Q_{t}^{N}-\left(1+r_{t-1}\right) Q_{t-1}^{N}\right) \\
& +\Delta Y_{t}^{N} Q_{t}^{i}+Y_{t-1}^{N}\left(Q_{t}^{i}-\left(1+r_{t-1}\right) Q_{t-1}^{i}\right)
\end{aligned}
$$

[A1]

Note from equation [2] and the definition of the provincial trade balance that provincial wealth can be rewritten as

[A2]

$$
Q_{t}^{i}=E_{t} \sum_{j=0}^{\infty} \frac{y_{t+j}^{i}-T B_{t+j}^{i}}{\prod_{k=0}^{j}\left(1+r_{t+k}\right)}
$$

and hence that the quasi-difference of wealth is:

$$
Q_{t}^{i}-\left(1+r_{t-1}\right) Q_{t-1}^{i}=\left(1+r_{t-1}\right)\left(Y_{t}^{i}-T B_{t}^{i}\right)+\epsilon_{t}^{i}
$$

[A3]

where $\epsilon_{\mathrm{t}}^{\mathrm{i}}$ is the 'news' about wealth at time $t$ obtained between times $t-1$ and $t$. $^{29}$

$$
\underset{\epsilon}{i}=\left(E_{t}-E_{t-1}\right) \sum_{j=0}^{\infty} \frac{y_{t+j}^{i}-T B_{t+j}^{i}}{\prod_{k=0}^{j}\left(1+r_{t+k}\right)}
$$

[A4]

A similar equation (excluding the term in the trade balance) holds for the quasi-difference of national future expected income available for consumption, including $\epsilon^{N}$, the expectational error for the region as a whole.

Substituting these results into equation [A1] gives:

${ }^{29}$ See Deaton (1992) (chapter 3) for a similar derivation in the context of the permanent income hypothesis. 


$$
\Delta T B_{t}^{i} Q_{t}^{N}+T B_{t-1}^{i}\left(\left(1+r_{t-1}\right) Y_{t-1}^{N}+\epsilon_{t}^{i}\right)
$$

[A5]

$$
\begin{aligned}
& =\Delta Y_{t}^{i} Q_{t}^{N}+Y_{t-1}^{i}\left(\left(1+r_{t-1}\right) Y_{t-1}^{N}+\epsilon_{t}^{i}\right) \\
& +\Delta Y_{t}^{N} Q_{t}^{i}+Y_{t-1}^{N}\left(\left(1+r_{t-1}\right)\left(Y_{t-1}^{i}-T B_{t}^{i}\right)+\epsilon_{t}^{N}\right)
\end{aligned}
$$

Since the terms in the levels of lagged incomes and trade balances all cancel, equation [A5] simplifies to;

$$
\Delta T B_{t}^{i} Q_{t}^{N}=\Delta Y_{t}^{i} Q_{t}^{N}-\Delta Y_{t}^{N} Q_{t}^{i}+\left(Y_{t-1}^{N} \epsilon_{t}^{i}+Y_{t-1}^{i} \epsilon_{t}^{N}-T B_{t-1}^{i} \epsilon_{t}^{N}\right)
$$

[A6]

While provincial wealth and national wealth are not observable, equation [4] shows that their ratio equals the ratio of provincial consumption to national consumption. Using this, a simple transformation of equation [A6] implies the following equation for the change in the trade balance:

$$
\Delta T B_{t}^{i}=\Delta Y_{t}^{i}-\Delta Y_{t}^{N} \frac{C_{t}^{i}}{C_{t}^{N}}+\epsilon_{t}
$$

[A7]

where the error, $\epsilon_{t}$, is a linear combination of the 'news' about current wealth of the province, $\epsilon_{t}^{i}$ and of the nation, $\epsilon^{N}$. Equation [A7] corresponds to equation [9] in the text. 


\section{BIBLIOGRAPHY}

Barro, Robert and Xavier Sala-i-Martin, "Convergence Across States and Regions," Brookings Papers on Economic Activity, 1991, vol. 1, pp. 107-158.

Bayoumi, Tamim and Ronald MacDonald, "Consumption, Income, and International Capital Market Integration," C.E.P.R. Discussion Paper No. 1028, October 1994.

Bayoumi, Tamim and Andrew Rose, "Domestic Saving and Intra-National Capital Flows," European Economic Review, vol. 37, no. 6, August 1993, pp. 1197-1202.

Blanchard, Olivier Jean and Lawrence F. Katz, "Regional Evolutions," Brookings Papers on Economic Activity, 1992, vol. 1, pp. 1-61.

Deaton, Angus, Understanding Consumption, 1992, (Oxford University Press: Oxford U.K.).

Engel, Charles and John Rogers, "How Wide is the Border?" N.B.E.R. Working Paper No. 4829, August 1994.

Frenkel, Jacob and Assaf Razin, Fiscal Policies and the World Economy, 1987 (The MTT Press: Cambridge, MA).

Ghosh, Atish R., "Capital Mobility Amongst the Major Industrial Countries: Too Little or Too Much?" Economic Journal, forthcoming.

Glick, Reuven and Kenneth Rogoff, "Global versus Country-Specific Productivity Shocks and the Current Account," International FInance Discussion Papers No. 443, Board of Governors of the Federal Reserve System, April 1993.

Lewis, Karen K., "What Can Explain the Apparent Lack of International Consumption Risk Sharing?" mimeo, University of Pennsylvania, July 1993.

Messinger, Hans, "Interprovincial Trade Flows of Goods and Services," Canadian Economic Observer, October 1993, pp. 3.8 - 3.14 (Statistics Canada: Ottawa).

Obstfeld, Maurice, "Are Industrial-Country Consumption Risks Globally Diversified?" in Leonardo Leiderman and Assaf Razin, eds., Capital Mobility: The Impact on Consumption, Investment and Growth, 1994a (Cambridge University Press: Cambridge U.K.)

Obstfeld, Maurice, "International Capital Mobility in the 1990s," in Peter Kenen, ed., Understanding Interdependence: The Macroeconomics of the Open Economy, 1994b (Princeton University Press: Princeton, New Jersey).

Obstfeld, Maurice and Kenneth Rogoff, "The Intertemporal Approach to the Current Account," N.B.E.R. Working Paper No. 4893, October 1994. 
Tesar, Linda L. and Ingrid M. Werner, "Home Bias and the Globalization of Securities Markets," N.B.E.R. Working Paper No. 4218, November 1992. 
Table 1. Provincial Income and Correlations Between Changes In Per Capita Income and Changes in the Trade Balance

\begin{tabular}{|c|c|c|c|}
\hline & $\begin{array}{c}1992 \text { GDP } \\
\text { (billions of C\$s) }\end{array}$ & $\begin{array}{c}\text { Change in Real } \\
\text { GDP }\end{array}$ & $\begin{array}{c}\text { Change in Income } \\
\text { Available } \\
\text { for Consumption }\end{array}$ \\
\hline Alberta & 72.9 & 0.52 & 0.96 \\
\hline $\begin{array}{l}\text { British } \\
\text { Columbia }\end{array}$ & 86.7 & 0.05 & 0.81 \\
\hline Manitoba & 24.0 & 0.22 & 0.92 \\
\hline $\begin{array}{l}\text { New } \\
\text { Brunswick }\end{array}$ & 13.9 & 0.48 & 0.97 \\
\hline $\begin{array}{l}\text { New- } \\
\text { foundland }\end{array}$ & 9.2 & 0.29 & 0.93 \\
\hline Nova Scotia & 18.0 & 0.26 & 0.82 \\
\hline Ontario & 277.5 & 0.19 & 0.75 \\
\hline $\begin{array}{l}\text { Prince } \\
\text { Edward } \\
\text { Island }\end{array}$ & 2.2 & 0.37 & 0.91 \\
\hline Quebec & 157.1 & 0.10 & 0.73 \\
\hline Saskatchewan & 20.2 & 0.10 & 0.98 \\
\hline $\begin{array}{l}\text { Yukon \& } \\
\text { Northwest } \\
\text { Territories }\end{array}$ & 3.1 & 0.32 & 1.00 \\
\hline Canada & 684.7 & 0.15 & 0.64 \\
\hline
\end{tabular}

Notes: All series are measured in 1986 Canadian dollars and are adjusted for differences in federal net lending. 
Table 2. Standard Deviation of Per Capita Variables

Thousands of 1986 Canadian Dollars)

\begin{tabular}{llll}
\hline & $\begin{array}{c}\text { Changes } \\
\text { in } \\
\text { Real GDP }\end{array}$ & $\begin{array}{c}\text { Changes in } \\
\text { Income } \\
\text { Available for } \\
\text { Consumption }\end{array}$ & $\begin{array}{c}\text { Changes } \\
\text { in Trade } \\
\text { Balance }\end{array}$ \\
\hline Alberta & 1.12 & 0.91 & 0.90 \\
British Columbia & 0.65 & 0.43 & 0.40 \\
Manitoba & 0.55 & 0.46 & 0.46 \\
New Brunswick & 0.51 & 0.58 & 0.55 \\
Newfoundland & 0.36 & 0.48 & 0.43 \\
Nova Scotia & 0.41 & 0.34 & 0.33 \\
Ontario & 0.61 & 0.33 & 0.25 \\
Prince Edward Island & 0.60 & 0.48 & 0.49 \\
Quebec & 0.47 & 0.30 & 0.29 \\
Saskatchewan & 0.87 & 0.90 & 0.92 \\
Yukon \& Northern Territories & 2.72 & 3.37 & 3.43 \\
Canada & & 0.26 & 0.19 \\
\hline & 0.53 & & \\
\hline
\end{tabular}

Notes: All series are adjusted for differences in federal net lending. 
Table 3

The Basic Model.

\begin{tabular}{|c|c|c|c|c|}
\hline \multicolumn{5}{|c|}{$\Delta \mathrm{TB}_{\mathrm{i}}=\alpha_{\mathrm{i}}+\beta_{\mathrm{i}}\left(\Delta \mathrm{Yi}-\Delta \mathrm{Y}_{\mathrm{OECD}}^{*}\right) \underline{1}$} \\
\hline & Constant & $\begin{array}{c}\text { Coefficient on } \\
\text { Income } \\
\end{array}$ & $\begin{array}{c}\text { Durbin-Watson } \\
\text { Statistic } \\
\end{array}$ & R-squared \\
\hline Alberta & $.00(.05)$ & $1.05(.08)^{* *}$ & 1.37 & 0.97 \\
\hline British Columbia & $-.01(.04)$ & $0.61(.18)^{* *}$ & 1.92 & 0.61 \\
\hline Manitoba & $.03(.03)$ & $0.93(.09)^{* *}$ & 1.70 & 0.83 \\
\hline New Brunswick & $-.03(.03)$ & $1.00(.07)^{* *}$ & 1.63 & 0.94 \\
\hline Newfoundland & $-.02(.02)$ & $0.90(.14)^{* *}$ & N4 & 0.86 \\
\hline Nova Scotia & $.00(.03)$ & $0.75(.10)^{* *}$ & 1.80 & 0.69 \\
\hline Ontario & $.02(.03)$ & $0.59(.17)^{* *}$ & 1.98 & 0.56 \\
\hline Prince Edward Island & $-.01(.03)$ & $0.88(.09)^{* *}$ & 1.55 & 0.87 \\
\hline Quebec & $-.02(.04)$ & $0.79(.18)^{* *}$ & 1.35 & 0.61 \\
\hline Saskatchewan & $.01(.05)$ & $1.12(.07)^{* *}$ & 1.64 & 0.92 \\
\hline $\begin{array}{l}\text { Yukon \& Northern } \\
\text { Territories }\end{array}$ & $.02(.06)$ & $0.99(.06)^{* *}$ & 1.87 & 0.99 \\
\hline Canada & $.01(.03)$ & $0.52(.18)^{* *}$ & 2.07 & 0.46 \\
\hline \multicolumn{5}{|l|}{$\begin{array}{l}\text { Wald Tests (on provincial } \\
\text { equations only): }\end{array}$} \\
\hline $\begin{array}{l}\text { Constant Termes are } \\
\text { Equal to } 0 \chi^{2}(12)\end{array}$ & 3.7 & & & \\
\hline $\begin{array}{l}\text { Income Coefficients are } \\
\text { Equal to } 1 \chi^{2}(12)\end{array}$ & & $24.2^{* *}$ & & \\
\hline $\begin{array}{l}\text { Income Coefficients are } \\
\text { Equal } \chi^{2}(11)\end{array}$ & & $21.7^{* *}$ & & \\
\hline \multicolumn{5}{|c|}{$\begin{array}{l}\text { Notes: All standard errors are adjusted for heteroscedascity. The instruments for the provincial } \\
\text { regressions were to first and second lags of the change in provincial income relative to adjusted } \\
\text { OECD income, the change in the provincial trade balance, the adjusted change in Canatian income } \\
\text { relative to adjusted OECD income, and the Canadian trade balance. For the Canadian regression } \\
\text { Canadian values were used in place of provincial ones, and OECD values in place of Canadian } \\
\text { ones. }\end{array}$} \\
\hline$\Delta Y_{\mathrm{OECD}}^{*}=($ & . & & & \\
\hline
\end{tabular}


Table 4

The Extended Model.

\begin{tabular}{|c|c|c|c|c|}
\hline \multicolumn{5}{|c|}{$\Delta \mathrm{TB}_{\mathrm{CAN}}=\lambda\left(\Delta \mathrm{Y}_{\mathrm{CAN}}-\Delta \mathrm{Y}_{\mathrm{OECD}}^{*}\right)^{1 /}$} \\
\hline & $\begin{array}{l}\text { Coefficient on } \\
\text { Provincial } \\
\text { Income }\end{array}$ & $\begin{array}{l}\text { Coefficient on } \\
\text { Canadian } \\
\text { Income }\end{array}$ & $\begin{array}{l}\text { Durbin } \\
\text { Watson } \\
\text { Statistic }\end{array}$ & $\overline{\mathrm{R}}^{2}$ \\
\hline Alberta & $1.07(.06)^{* *}$ & $-0.57(.35)$ & 1.87 & 0.94 \\
\hline British Columbia & $0.46(.40)$ & $0.36(.58)$ & 2.01 & 046 \\
\hline Manitoba & $1.22(.12)^{* *}$ & $-1.24(.40)^{* *}$ & 2.32 & 0.88 \\
\hline New Brunswick & $1.00(.07)^{* *}$ & $-0.04(.18)$ & 1.64 & 0.94 \\
\hline Newfoundland & $0.90(.11)^{* *}$ & $-0.53(.26)^{*}$ & 1.75 & 0.92 \\
\hline Nova Scotia & $1.13(.21)^{* *}$ & $-0.92(.49)$ & 2.31 & 0.69 \\
\hline Ontario & $0.95(.29)^{* *}$ & $-0.61(.40)$ & 2.42 & 0.53 \\
\hline Prince Edward Island & $0.94(.14)^{* *}$ & $-0.30(.55)$ & 1.74 & 0.89 \\
\hline Quebec & $1.08(.24)^{* *}$ & $-0.44(.28)$ & 1.74 & 0.72 \\
\hline Saskatchewan & $1.16(.07)^{* *}$ & $-0.61(.31)$ & 1.48 & 0.95 \\
\hline $\begin{array}{l}\text { Yukon \& Northern } \\
\text { Territories }\end{array}$ & $1.02(.06)^{* *}$ & $-1.50(1.47)$ & 2.48 & 0.99 \\
\hline Canada & $0.52(.18)^{* *}$ & & 2.07 & 0.46 \\
\hline \multicolumn{5}{|l|}{$\begin{array}{l}\text { Wald Tests (on provincial } \\
\text { equations only): }\end{array}$} \\
\hline $\begin{array}{l}\text { Income Coefficients are } \\
\text { Equal to } 1 \chi^{2}(11)\end{array}$ & 12.9 & & & \\
\hline $\begin{array}{l}\text { Income Coefficients are } \\
\text { Equal to } 0 \chi^{2}(11)\end{array}$ & & $31.2 * *$ & & \\
\hline $\begin{array}{l}\text { Income Cqefficients are } \\
\text { Equal } \chi^{2}(10)\end{array}$ & & 13.3 & & \\
\hline $\begin{array}{l}\text { Income Coefficients are } \\
\text { Equal Plus Restriction } \\
\text { on } \mathcal{C}^{2} \text { anadian Equation } \\
\chi^{2}(11)\end{array}$ & & 13.3 & & \\
\hline
\end{tabular}

Notes: See Table 1.

1/ $\Delta \mathrm{Y}_{\mathrm{OECD}}^{*}=\left(\mathrm{C}_{\mathrm{i}} / \mathrm{C}_{\mathrm{OECD}}\right) \Delta \mathrm{Y}_{\mathrm{OECD}} \cdot \Delta \mathrm{Y}_{\mathrm{CA}}^{*}=\left(\mathrm{C}_{\mathrm{i}} / \mathrm{C}_{\mathrm{CA}}\right) \Delta \mathrm{Y}_{\mathrm{CA}} \cdot$ 
Table 5

Constrained Model Results

$$
\begin{gathered}
\Delta \mathrm{TB}_{\mathrm{i}}=\Delta \mathrm{Y}_{\mathrm{i}}-(1-\delta) \Delta \mathrm{Y}_{\mathrm{CA}}^{*}-\delta \Delta \mathrm{Y}_{\mathrm{OECD}}^{*} \\
\Delta \mathrm{TB}_{\mathrm{CA}}=\delta\left(\Delta \mathrm{Y}_{\mathrm{CA}}^{*}-\mathrm{Y}_{\mathrm{OECD}}^{*}\right) \underline{1} /
\end{gathered}
$$

\begin{tabular}{lll}
$\begin{array}{l}\text { Proportion of Consumption } \\
\text { constrained outside Canada }\end{array}$ & $\begin{array}{c}\text { Durbin- } \\
\text { Watson Statistic }\end{array}$ & $\overline{\mathrm{R}}^{2}$ \\
Regional Results & 1.57 & 0.95 \\
\hline Alberta & 2.05 & 0.72 \\
British Columbia & 1.88 & 0.92 \\
Manitoba & 1.87 & 0.94 \\
New Brunswick & 1.35 & 0.91 \\
Newfoundland & 2.04 & 0.79 \\
Nova Scotia & 1.82 & 0.59 \\
Ontario & 1.87 & 0.89 \\
Prince Edward Island & 1.87 & 0.74 \\
Quebec & 1.54 & 0.96 \\
Saskatchewan & 2.13 & 0.99 \\
Yukon and Northwest Territories & & 0.48 \\
Canada & 2.00 & \\
\hline
\end{tabular}

Notes: See Table 1.

1/ $\Delta \mathrm{Y}_{\mathrm{OECD}}^{*}=\left(\mathrm{C}_{\mathrm{i}} / \mathrm{C}_{\mathrm{OECD}}\right) \Delta \mathrm{Y}_{\mathrm{OECD}} \cdot \Delta \mathrm{Y}_{\mathrm{CA}}^{*}=\left(\mathrm{C}_{\mathrm{i}} / \mathrm{C}_{\mathrm{CA}}\right) \Delta \mathrm{Y}_{\mathrm{CA}}$. 
Chart 1. Canada: Change in GDP, Income, and Trade Balance.

(In thousands of 1986 dollars per capita)

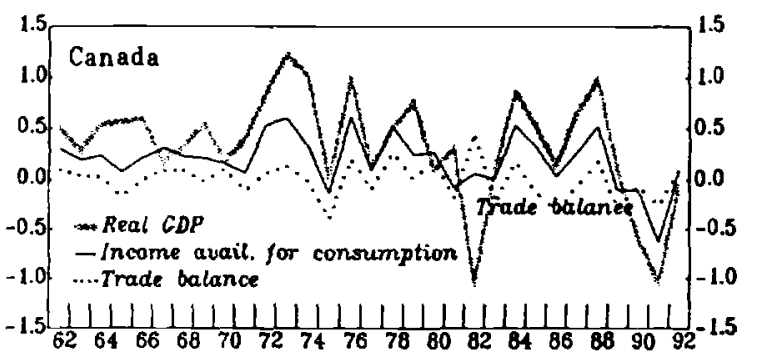

Alberto

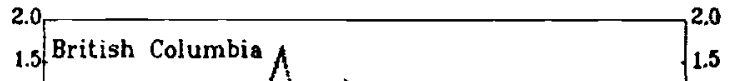

$\underset{0.5}{0.5}$

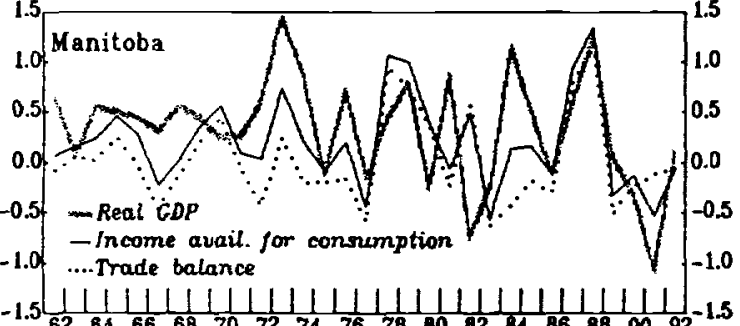

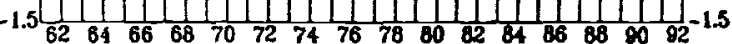
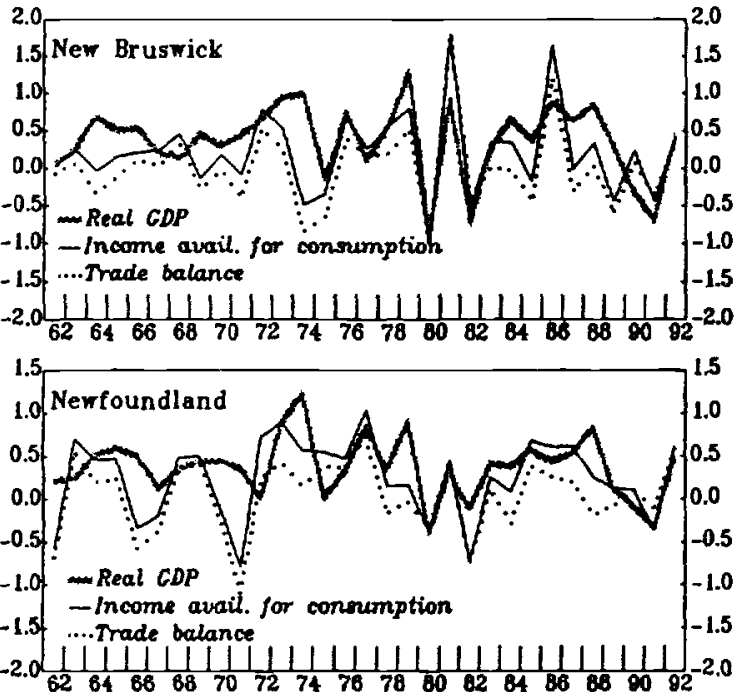
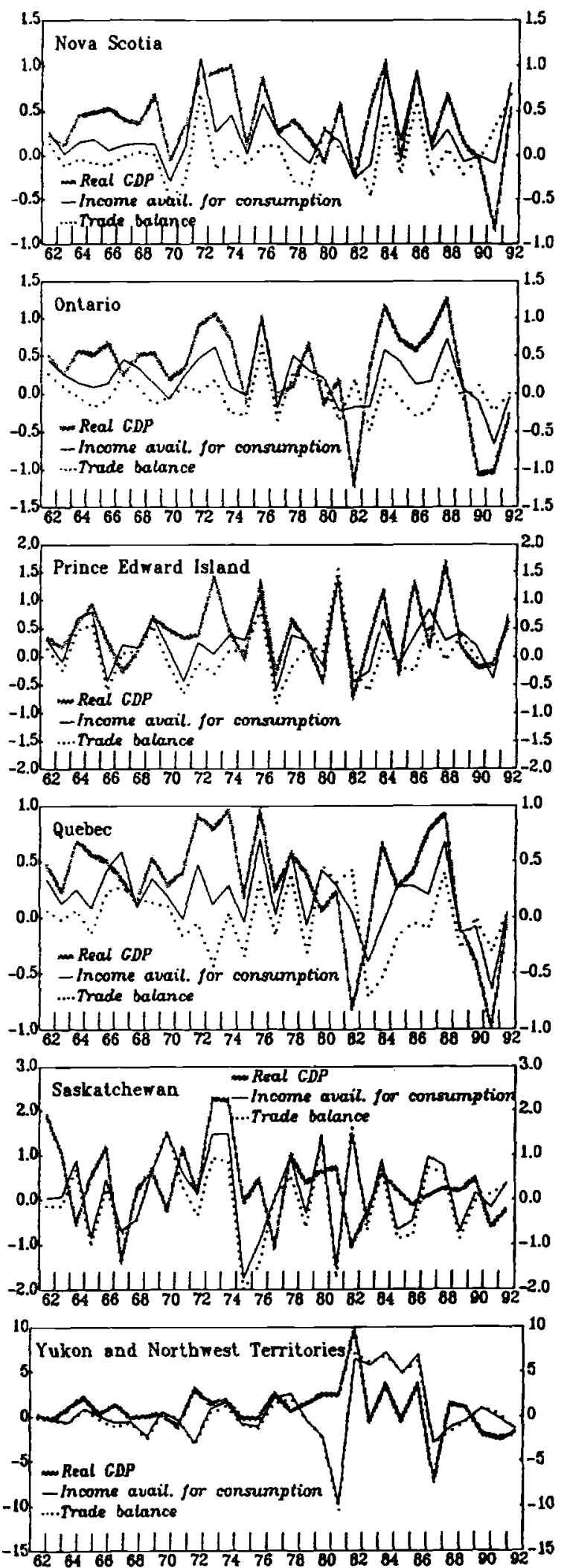
Chart 2. Canada: GDP, Income, and Trade Balance.

(In thousands of 1986 dollars per capita)
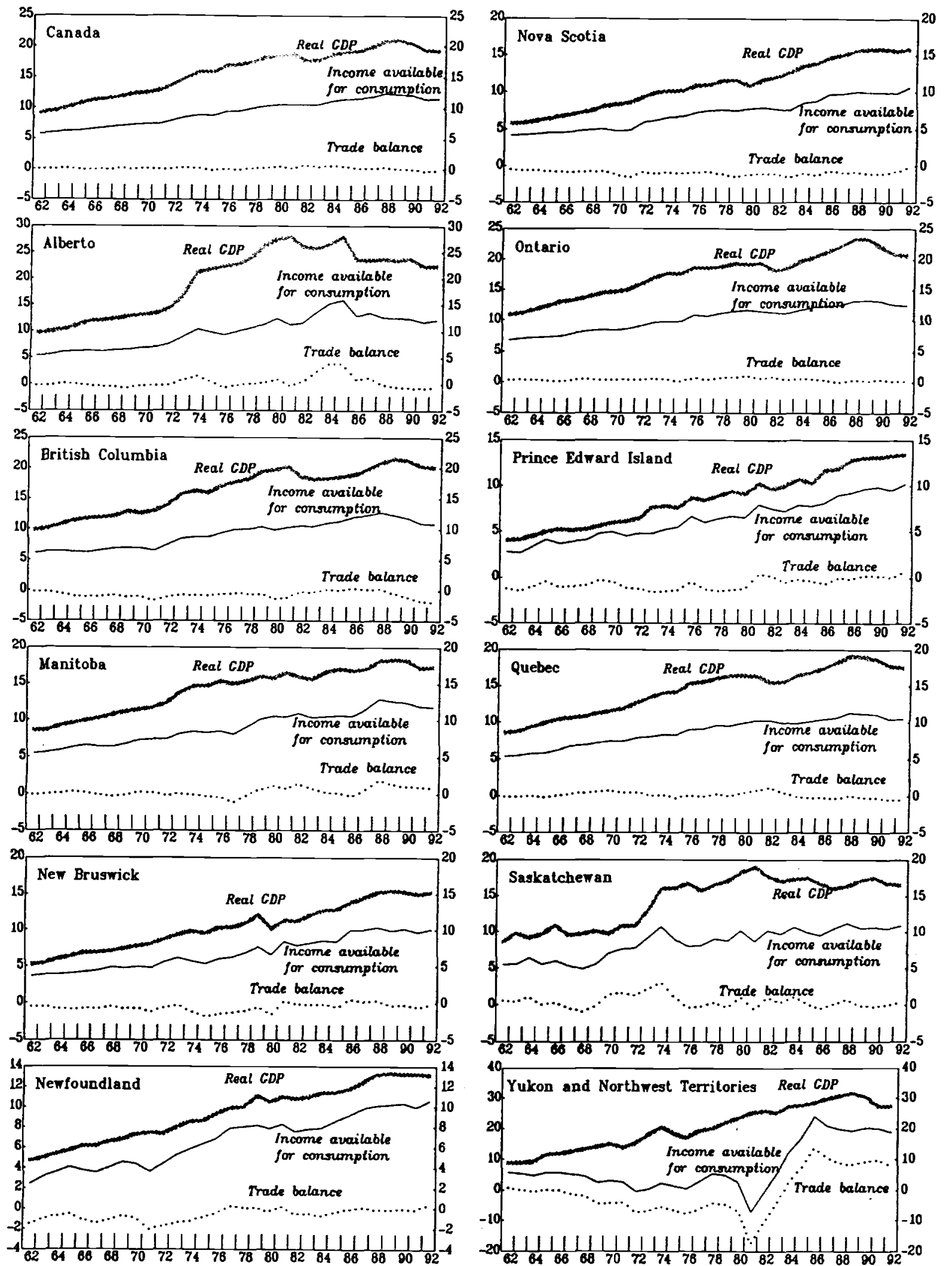